IFN Working Paper No. 809, 2009

\title{
Can Investment in Intangibles Explain the Swedish Productivity Boom in the 1990s?
}

Harald Edquist 


\title{
Can Investment in Intangibles Explain the Swedish Productivity Boom in the 1990s?*
}

\author{
By
}

\author{
Harald Edquist ${ }^{\dagger}$
}

2009-11-08

JEL-codes: E01; E22; O16; O47

Key-words: Intangibles; Investment; Economic growth

\begin{abstract}
After a severe crisis in the early 1990s, the Swedish economy experienced a boom in productivity growth. Economists have presented three explanations for the fast productivity growth in 1995-2004: market reforms, crisis recovery and the impact of information and communication technology (ICT). This paper offers an alternative view, emphasizing instead firms' substantial investment in intangible assets such as R\&D, design, and advertising. These investments are not classified as investment in the National Accounts, however, in which only tangible assets are defined as investment. This paper provides estimates of investment in intangible assets and uses the growth accounting framework to analyze the Swedish productivity boom. The results show that investment in intangibles was approximately 246 billion SEK in 2004 or 9 percent of GDP. Moreover, intangible capital accounted for almost 35 percent of labor productivity growth in the Swedish business sector in 1995-2004. Thus, the Swedish TFP growth that was one of the highest among OECD-countries was reduced substantially when investment in intangibles was included in the growth accounting analysis 1995-2004. In the period 1995-2000, TFP growth was only 0.4 percentage points - almost all labor productivity growth could be explained by factor inputs, while in 2000-2004 TFP growth was considerably larger.
\end{abstract}

Financial support has been provided by the COINVEST project, www.coinvest.org.uk, funded by the European Commission Seventh Framework Programme, Theme 9, Socio-economic Science and Humanities, grant number 217512.

\footnotetext{
* I am grateful for useful comments and suggestions from Jonathan Haskel, Henrik Jordahl, Annarosa Pesole and participants at the COINVEST seminar in Mannheim, OECD-workshop in Paris and seminars at the Research Institute of Industrial Economics in Stockholm. Financial support from the European Commission is also gratefully acknowledged.

${ }^{\dagger}$ Research Institute of Industrial Economics, Box 55665, SE-102 15 Stockholm, Sweden, Phone: +468-6654520, Fax: +46-8-6654599.
} 


\section{Introduction}

After a severe economic crisis in the early 1990s, productivity growth began to increase in Sweden in the mid-1990s. Many economists thought then that the high productivity growth could be ascribed to the recovery in wake of the crisis - and that it would evaporate after a few years. But productivity growth remained high throughout 1995-2005, even during the economic slowdown in the beginning of the millennium. In fact, productivity growth in the Swedish business sector was one of the highest throughout the western world (see figure 1).

Economists have traced the reasons behind why productivity growth in the Swedish business sector has remained considerably higher than in many other industrialized countries to two things: the effects of market reforms in the 1980s and the revolution in information and communication technology (ICT). Market reforms are believed to affect competition, thereby increasing resource efficiency and thus productivity (Nickell 1996). In theory, efficient markets also lead to increased diffusion of new technology and increase the incentives to innovate. But despite the evidence of a positive impact of increased competition on productivity growth, long time lags have hampered the ability to establish direct links between Swedish market reforms in the 1980s and productivity growth in the 1990s.

According to Schumpeter (1939), innovation is crucial for economic growth. During the last decades, breakthroughs in ICT have spurred a technological revolution. The invention of the transistor launched the revolution that generated innovations such as the semiconductor and the integrated circuit, the Internet and cell phones. Although these new products were available on the market, their effect on macroeconomic productivity growth materialized slowly. ${ }^{1}$ Several studies have shown that ICT has had a significant impact on productivity growth in Sweden since the mid-1990s (Edquist and Henrekson 2006; Edquist 2008). Similar evidence was found for the United States economy (van Ark, O’Mahony and Timmer 2008; Oliner and Sichel 2000; Jorgenson 2001; Jorgenson, Ho and Stiroh 2008; Stiroh 2002).

\footnotetext{
${ }^{1}$ This was named the Solow paradox after Nobel Laureate Robert Solow's famous remark that "you can see the computer age everywhere but in the productivity statistics" (Solow 1987).
} 
Although ICT investment remained important for productivity growth after the turn of the millennium, its relative impact began to decrease (Jorgenson et al. 2008; Edquist 2008). Instead, total factor productivity growth increased in both Sweden and the US. Thus, the increase in productivity failed to remove all suspicion surrounding the ability of official data to accurately capture the factors that affect economic growth (Corrado, Hulten and Sichel 2006). In response, several studies have pointed to investment in intangible assets as an additional explanation for economic growth (Corrado et al. 2005; 2006; 2009; Fukao, Miyagawa, Mukai, Shinoda and Tonogi 2009; Hao, Manole and van Ark 2009; Marrano and Haskel 2006; Marrano, Haskel and Wallace 2009; van Rooijen-Horsten, van den Bergen and Tanriseven 2008).

In the Swedish national accounts, intangibles have been treated as an intermediate expense and not as an investment. ${ }^{2}$ Indeed, intangibles are considered difficult to measure compared to tangible assets such as buildings and machinery. Nevertheless, many advanced economies are moving towards "knowledge economy" activities, in which intangible assets play a large role (Marrano and Haskel 2006). As some economies have become more dependent on high-tech products and knowledge intensive services, investment in intangible assets such as education and research and development has increased. Intangible investment can be defined as expenditures by businesses intended to boost output in the future that do not take the form of traditional physical capital (Corrado et al. 2005; 2006). Unlike physical capital, its value does not appear on a firm's balance sheet. ${ }^{3}$

To my knowledge, the impact of intangibles on the Swedish economy has never been systematically explored at the macro-level. ${ }^{4}$ Thus, this paper will use the methods developed by Corrado et al. (2006) and Marrano and Haskel (2006) to estimate expenditures and investment in intangibles in the Swedish business sector in 19932004. The results will then be compared with similar results for the United Kingdom and the United States. Based on these estimates, the growth accounting framework

\footnotetext{
${ }^{2}$ Computer software defined as an intangible capital in this paper is included in the Swedish GDP figures.

${ }^{3}$ As opposed to tangible assets, the value of intangibles is highly uncertain; a competitive market for intangible assets often does not exist.

${ }^{4}$ Eliasson (2000) investigates the impact of some intangibles on the 9 and 17 largest manufacturing firms in Sweden.
} 
will be used to investigate how important investment in intangibles was for economic growth and productivity growth in Sweden in 1995-2004.

The following questions will be investigated:

- How large were intangible spending and investment in the Swedish business sector in 2004 ?

- How does intangible investment in Sweden compare to other countries like the UK and the US?

- How important was investment in intangibles for economic growth and productivity growth in the Swedish business sector 1995-2004?

\section{Data and sources}

Corrado et al. (2006) and Marrano and Haskel (2006) focus on intangible investment in the business sector. To facilitate the comparison of their results with the Swedish data, this paper will only address investment in intangibles in the business sector. Intangible investment in the public sector is also important, and will be explored in future papers. ${ }^{5}$

This paper follows the methodological framework set up by Corrado et al. (2006). According to Corrado et al., intangible assets can be organized in three main groups:

1. Computerized information (software, computerized databases)

2. Innovative property (research and development [R\&D], mineral explorations, copyright and license cost, product development in financial industries and design)

3. Economic competencies (brand equity, vocational training and organizational capital)

\footnotetext{
${ }^{5}$ Sweden has a large public sector compared to both the US and the UK. This implies that comparisons of investment in intangible assets in the private sector expressed as a percentage of total GDP could be affected.
} 
Various methods and surveys are used to estimate the spending on such assets for the years 1993-2004. The specific methods and sources for Sweden are described below. It should be noted that the spending only measures the total expenditure on a specific asset and therefore includes both current consumption and deferred consumption in some cases. Only deferred consumption can be considered as investment; as a result, different methods are used to separate the spending on current production from actual spending that is made to expand future productive capacity (see section 3 ).

\subsection{Computerized information}

\subsubsection{Computer software}

The estimates for computer software stem from the EU KLEMS (2008), a database financed by the European Commission to analyze productivity in the European Union at the industry level. The database includes measurements of output growth, employment, skill creation, capital formation and total factor productivity at the industry level. Investment is measured by nominal gross fixed capital formation (GFCF) in software for Sweden during the years between 1993 and 2004. Investment for the public sector is excluded.

\subsubsection{Computerized databases}

Spending on computerized databases is already included in the estimates of software spending provided by the EU KLEMS (2008) database for Sweden.

\subsection{Innovative property}

\subsubsection{Research and development (R\&D)}

R\&D expenditure data for Sweden is derived from the ANBERD database (OECD 2006). The ANBERD database exists to create a consistent data set that covers business enterprise expenditures on R\&D (BERD) in OECD countries, as delineated by the Frescati Manual (2002). According to the Frescati Manual, R\&D is defined as "creative work undertaken on a systematic basis in order to increase the stock of knowledge, including knowledge of man, culture and society, and the use of this stock 
of knowledge to devise new applications."

R\&D should include an appreciable element of novelty and involve the resolution of scientific and technological uncertainty. Thus, it is likely that most reported R\&D is of a scientific nature - items such as design and market research will not be included in R\&D figures. Moreover, in order to avoid double counting with software figures, total $\mathrm{R} \& \mathrm{D}$ spending was deducted with the $\mathrm{R} \& \mathrm{D}$ spending on computer and related activities. ${ }^{6}$ Moreover, R\&D figures for social science and humanities in the business sector were added based on data from Statistics Sweden. ${ }^{7}$

\subsubsection{Mineral exploration}

Mineral exploration is based on data from the Geological Survey of Sweden. It primarily covers the prospecting of new ore deposits with the expectation of future returns (as opposed to expenditure on ore-mining to extract existing ore deposits).

\subsubsection{Copyright and license cost}

Corrado et al. (2006) estimate copyright and license costs in line with the development of motion pictures and that of radio, television, sound recording and book publishing. Unfortunately, there is no available data that describes development costs for Swedish radio, television, sound recording and book publishing. However, data for the development costs of Swedish motion pictures exists, based on Screen Digest (2005). Moreover, there is also data on the turnover of motion pictures and video production and sound recording. Thus, the ratio of investment in motion picture over the total turnover of the industry can be estimated. ${ }^{8}$ It then is assumed that the

\footnotetext{
${ }^{6}$ For the year 2005 data is based on figures provided by Statistics Sweden. Moreover, for the years 2004 and 2005 it is assumed that R\&D spending on computer and related activities were the same as in 2003 since data is missing.

${ }^{7} \mathrm{R} \& \mathrm{D}$ in social science and humanities is measured as the output of the industry producing social science research (SNI 732). The expenditure is multiplied with a factor of 2 to capture own account spending. Moreover, in 2005, R\&D in social science and humanities only accounted for 0.3 percent of total R\&D spending.

${ }^{8}$ Data on the development costs of motion pictures is only available for the period 2000-2004. For the years 1993-1999 and 2005, it is assumed that the investment/turnover ratio is the same as the average for the years 2000-2004.
} 
video production and sound recording industry has the same investment/turnover ratio as the motion picture industry.

\subsubsection{Development costs in financial services}

Corrado et al. (2006) measure product development in the financial services industry to be 20 percent of total intermediate spending by financial services. I therefore use the measure of intermediate service input, which excludes intermediate spending in the manufacturing sector. According to Marrano and Haskel (2006), intermediate spending can be problematic because it includes the purchase of advertising, software, consulting services and architectural and engineering activities, which are calculated elsewhere in the spending calculations. Unfortunately, however, spending on these activities cannot be subtracted from the Input-Output tables, because there is only data available at the 2-digit industry level. The source of the intermediate service spending is EU KLEMS (2008).

\subsubsection{Design}

It is important to understand what is meant by design before trying to quantify the extent of design as an economic activity. Distinguishing design from other activities matters because several design-related activities are already counted in the formation of capital in the National Accounts. According to Marrano and Haskel (2006), design activity can be defined by the relationship between design activities and the official measurement of R\&D under the Frescati Manual framework. The Manual states that if design is made for the setting up and operating of pilot plants and prototypes, these costs should be included in R\&D. However, if design is carried out for the preparation, execution and maintenance of production standardization or to promote the sale of products, they should be excluded from the definition of R\&D.

The System of National Accounts (1993) specifies the convention regarding the treatment of design services. Accordingly, these services should be fully used up or fully transformed by the production process. This implies that design services are treated in most cases as intermediate consumption, not as capital investment. It also 
suggests that the costs of in-house design activities are deemed not to generate an independent output and so not counted as a separate product.

In Corrado et al. (2006), half of the turnover of the architectural and design industry was used as a proxy for purchased and own account expenditure on architectural and engineering design (AED). However, purchased and own account design activities are estimated by more sophisticated methods in this paper: both the AED services bought in the marketplace and the AED services produced in-house for internal use will be measured.

Galindo-Rueda, Haskel and Pesole (2008) estimate design expenditures in the UK by using wages earned by designers and supply-use tables for the product group architectural activities and technical consultancy. Unfortunately, it has not been possible to obtain supply-use tables for Sweden at the disaggregated level needed to measure the supply of architectural activities and technical consultancy services. Thus, the methods used in this paper will differ from the methods developed by Galindo-Rueda et al. (2008).

The AED services bought in the market place are estimated as the turnover of the architectural activities and technical consultancy industry (SIC 742). Due to the lack of supply-use tables, it has not been possible to estimate how much of the market design services that are actually produced by SIC 742 . Nonetheless, the total output is weighted by the share of the total proportion of employment in SIC 742 that is related to design occupations. Based on Galindo-Rueda et al. (2008), the following occupations have been defined as design occupations: architects and town planners (SSYK 2141), civil engineers (SSYK 2142), electrical engineers (SSYK 2143), electronics and telecommunications engineers (SSYK 2144), mechanical engineers (SSYK 2145), chemical engineers (SSYK 2146), designers (SSYK 2456) and decorators and commercial designers (SSYK 3471). ${ }^{9}$ Thus the spending on purchased design activities can be written ${ }^{10}$ :

\footnotetext{
${ }^{9}$ SSYK is the Swedish Standard Classification of Occupations.

${ }^{10}$ For some engineering occupations, it is likely that the employees to some extent is also involved in R\&D activities which then implies double counting. This problem is further discussed in Appendix A.
} 


$$
Y_{p}=Y^{742} \cdot \frac{N^{742 A E D}}{N^{742}}
$$

Where, $Y_{p}$ is the measured purchased AED output, $Y^{742}$ is the output of SIC 742 and $N^{742 A E D}$ is the number of employees with design occupations in SIC 742 and $N^{742}$ is the number of employees in SIC 742.

To estimate the AED produced by industries outside SIC 742 (own-account), we divide purchased AED $\left(Y_{p}\right)$ with the wage bill of designers in SIC $742\left(w N^{742 A E D}\right)$. Thus, a ratio indicating the output per invested wage unit in SIC 742 is obtained. It is then assumed that each invested wage unit is the same for persons with design occupations both working within SIC 742 and outside. This implies that by multiplying this ratio $Y_{p} / w N^{742 A E D}$ with the wage bill of persons with design occupations not working in SIC $742\left(w N^{B A E D}\right)$ we obtain the own account output. This can be expressed in the following formula:

$$
Y_{o w n}=\frac{Y_{p}}{w N^{742 A E D}} \cdot w N^{B A E D}
$$

where $Y_{\text {own }}$ is the own account output, $Y_{p}$ the purchased output. ${ }^{11}$

\footnotetext{
${ }^{11}$ Data for all variables in equation 1 and 2 is available for the period 1997-2005. For the period 199596 the wage bill has been estimated based on the average ratio of wage bill/turnover for the years 1997-2005. Moreover, data on the number of persons employed in SIC 742 1995-96 are based on the average ratio of employment in SIC 742 and total employment in 1997-2005.
} 


\subsection{Economic competences}

\subsubsection{Brand equity}

\subsubsection{Advertising}

Data on spending on advertising comes from the Swedish Institute for Advertisement (IRM). Data on classified ads were deducted based on figures for 2007. Classified ads then accounted for approximately 8 percent of total advertisement and 35 percent of the advertisement in newspapers. ${ }^{12}$

The available data includes the public sector. According to a survey by SIFO Research International, the government sector answered for approximately 1.1 percent of total spending on advertisement. Hence, it is assumed that this share is the same for the period 1993-2004; total investment is deducted by 1.1 percent for each year. However, this does not include the investments made by "Svenska Spel," the stateowned gambling company.

\subsubsection{Market Research}

Expenditure on market research is measured as twice the turnover of the market and consumer research industry (ISIC 7413). The estimation is based on the assumption that own account market research equals purchased market research.

\subsubsection{Vocational training}

Spending on vocational training is measured using data on how much firms in the business sector spent on continuing vocational training (CVT). The source is a survey of employer provided training conducted by Statistics Sweden in 1999 (CVTS 1999). A similar survey was carried out in 2005, but it was never published by Statistics Sweden due to a low response ratio.

CVTS (1999) measures the direct and indirect costs of continuing vocational training in firms with at least 10 employees as a percentage of total labor costs in 1999. Thus,

\footnotetext{
${ }^{12}$ It is assumed that classified ads also accounted for 8 percent of the total spending on advertisement for the period 1995-2005.
} 
to measure the spending on vocational training for all firms, it is assumed that firms with less than 10 employees spend the same proportion of their total labor costs on vocational training. Moreover, it is assumed that the proportion of labor costs spent by firms in 1993-2004 is the same as in 1999. This assumption must be made because reliable data on continuing vocational training is only available for the year 1999 .

\subsubsection{Organizational structure}

\subsubsection{Purchased organizational structure}

Investment in organizational structure (OS) includes investment in purchased OS and own account OS. Purchased OS is measured with the turnover of business and management consultancy activities (SIC 7414). The turnover has been adjusted so that only products that include services that affect organizational structure are included. ${ }^{13}$ Moreover, the share of the turnover purchased by the public sector is excluded based on data from the Swedish business magazine Affärsvärlden (2001-2004). ${ }^{14}$

\subsubsection{Own account organizational structure}

Investment in own-account organizational structure is measured as 20 percent of managers' compensation. The occupation used for managers is "legislators, senior officials and managers." However, legislators and senior government officials are excluded because the public sector is excluded, but senior officials working for special-interest organizations are still included.

The data is based on Statistics Sweden. Wage data for each group of managers is available for the period 1997-2005. There are no wage data available for the period 1993-1996 for each group of managers. Therefore, it has been assumed that the wages follow the average development for wages in the private sector and that the number of managers remained the same as in 1997.

\footnotetext{
${ }^{13}$ The following services are assumed to affect organizational structure: advise regarding distribution, employees, mergers and acquisition, organizations, taxes, marketing, production, project leadership and administration. It has only been possible to estimate the share of these services for the year 2006; the same share is therefore used to estimate purchased organizational structure for other years.

${ }^{14}$ It is assumed that the share of turnover purchased by the public sector is the same for the period 1995-2000 as the average share for the period 2001-2004.
} 


\section{Results of intangible spending and investment}

\subsection{Intangible spending in Sweden}

Table 1 shows that the total spending on intangibles in Sweden in 2004 was 300 billion SEK. Thus, the spending was approximately 11 percent of total GDP and 17 percent of total value added in the business sector. Table 1 also shows the spending for the different categories of intangibles. The largest expenditure was on R\&D, at 68 billion or 23 percent of total spending on intangibles. This corresponds well with the general view of Sweden as a R\&D-intensive country. Spending on design, software, advertising, vocational training and purchased organizational structure was also considerable. In fact, together with R\&D, these categories of assets accounted for almost 90 percent of total spending on intangibles.

Spending on own account organizational structure was 15 billion SEK, accounting for 5 percent of total spending. For all other categories of intangibles, spending came to 2 percent or less of the total expenditure on intangibles. Spending on mineral exploration was as low as 0.1 percent of total spending.

\subsection{How much of the spending is investment?}

According to Corrado et al. $(2005,2009)$ and Marrano et al. (2009), not all spending on intangibles can be considered as investment. It is necessary to separate the expense of current production from outlays that expand future productive capacity. For physical capital, this distinction is often made on the basis of the durability or expected service life of a purchase. Yet the service life of a specific asset can be ambiguous at times. For example, the definition used by the Bureau of Economic Analysis (BEA) might differ depending on the sector being considered. The BEA estimates that business fixed assets have a useful service life of at least three years, but some studies define business sector equipment as having a service life of more than one year. 
Based on this logic, Corrado et al. (2005) estimate the proportion of spending that can be considered as investment based on four steps:

1. If economic research has clearly shown that a given type of spending is fixed investment, then 100 percent is classified as capital investment.

2. If economic research suggests that only a portion of the spending on an intangible pays off in future year (or years), these findings are applied.

3. When there is strong suspicion that the lifetime of a type of intangible may not be at least three years, the item is discounted by 20 percent and a range of estimates of capital investment is shown for the item.

4. When there is strong suspicion that a portion of the spending may be for routine tasks or represent current consumption, the point estimate is discounted 20 percent.

It is recognized that these steps do not provide a precise measure of the spending that can be considered to be capital investment. In particular, the last two steps are vague and the discounted percentage is arbitrary. Nevertheless, the results by Corrado et al. (2005) show that business spending on intangibles was a substantial and growing component of the economy in the 1990s. It is essential, however, that future research try to improve these methods.

Table 1 shows the proportion of spending considered as investment according to Corrado et al. (2005). Little is known about the service life of software, yet the BEA assumes a three year service life for all prepackaged software and a five year service life for custom and owned software. Therefore Corrado et al. (2006) assume that 100 percent of total spending on computerized information should be classified as capital investment. The same rule applies for scientific R\&D spending, mineral exploration, copyright and license costs and development costs in financial services.

Based on estimates provided by Gallindo-Rueda et al. (2008), only 50 percent of design spending should be counted as investment, as economic research on marketing has found that the effects of advertising are generally short lived. According to Landes and Rosenfield (1994), however, more than half of the expenditure on advertising has a service life of at least one year and one-third makes a cutoff of three 
years. Thus, Corrado et al. (2005) estimate that approximately 60 percent of total advertising expenditures have long lasting effects. In addition, continuing vocational training has long lived effects and is therefore counted as investment. Spending on organizational change also has likely long-lived effects, but only 80 percent is considered as investment, as a portion of purchased management expertise comprises rather routine tasks

It is evident that the process of estimating how much spending is actually investment is in many cases not very precise, and is rather based on ad hoc assumptions. Nevertheless, an attempt to measure investment in intangibles must use the best available information. Moreover, for some of the more important types of intangibles like scientific R\&D and vocational training, the service life is without doubt at least 3 years and 100 percent of the spending should therefore be counted as investment.

Figure 2 shows that the spending on intangible assets was approximately 11 percent of GDP in 2004. Based on the method described above, the total investment in intangibles is estimated to be 246 billion SEK or 9 percent of GDP. The Swedish investment in fixed capital for the business sector in 2004 was 361 billion SEK or 14 percent of GDP. Hence, the estimated investment in intangibles was almost two-thirds of the investment in physical capital. This clearly shows that investment in intangibles was considerable in comparison with investment in physical capital.

It is also interesting to note that in 1960, investment in physical capital in the Swedish business sector came to 22 percent of GDP. Investment in physical capital has thus decreased considerably in the Swedish business sector since 1960. However, if investment in intangible capital is added to physical capital, total investment reaches the figure of 23 percent of GDP. There are no estimates available for intangible capital in 1960, but it is likely that investment in intangibles was much lower in 1960 compared to 2004. Thus, it is not necessarily true that investment in the Swedish economy has decreased quite rapidly, as many economists have argued. It is more likely that the structure of the Swedish economy has become more service-based. 


\subsection{Comparisons with other countries}

Figure 3 shows investment in intangibles as a share of total GDP and business sector value added in Sweden, Japan, the UK and the US. In terms of GDP, the US had the highest investment in intangibles with 12 percent of GDP, while Japan had the second highest with 11 percent of GDP. Sweden and the UK had approximately the same investment ratio, namely 9 percent of GDP.

In terms of business sector value added, the investment ratio was still highest in the US with 18 percent. Sweden had the second highest investment ratio with 16 percent, while the corresponding figures for the UK and Japan were 15 percent. It is interesting to note that the investment ratio in Sweden increases more than in other countries in terms of business sector value added instead of GDP, which can be traced to the fact that Sweden has a larger public sector than the other countries. Since only business sector investment in intangibles is measured, business sector value added would constitute the correct measure to use for comparisons between countries, rather than GDP.

Figure 4 shows relative investment in intangibles for Japan, Sweden, the UK and the US based on the three sub-categories: Computerized information, innovative property and economic competencies. According to figure 4 the share of investment in computerized information was approximately the same in the four countries. For the US the share was 14 percent, while it was approximately 20 percent for the other countries. However, investment in economic competencies in the UK and the US were larger than investment in innovative property in relative terms. The opposite was found for Japan and Sweden, where innovative property was larger in relative terms. The difference between the two categories were not very large in Sweden and the US, while relative investment in innovative property was considerably larger in Japan and relative investment in economic competencies considerably larger in the UK.

\section{Growth accounting methodology}

Growth accounting methodology analyzes the impact of intangibles on productivity growth and labor productivity growth. The model used is the same as Corrado et al. 
(2006) and Marrano et al. (2009). It assumes that there are three goods produced: a consumption good, with real output volume $C_{t}$ and price $P_{t}^{C}$; a tangible investment good, $I_{t}$ with price $P_{t}^{I}$; and an intangible investment good, $N_{t}$ with price $P_{t}^{N}$, where the subscript denotes time. In Swedish national accounts, most intangibles are treated as intermediates, although it could be argued that they should be treated as capital.

\subsection{Intangibles treated as intermediates}

Assume that the intangible investment good is regarded as an intermediate. Then the tangible capital stock $K_{t}$ is assumed to accumulate according to the perpetual inventory method:

$K_{t}=I_{t}+\left(1-\delta_{K}\right) K_{t-1}$

with depreciation rate $\delta_{K}$. Suppose that factors are paid their marginal product and the production function is homogenous of degree 1 . Then it is possible to denote the production function and money flows for each sector as follows:

(a) Intangible sector:

$N_{t}=F^{N}\left(L_{N, t}, K_{N, t}, t\right) ; P_{t}^{N} N_{t}=P_{t}^{L} L_{N, t}+P_{t}^{K} K_{N, t}$

(b) Tangible sector:

$I_{t}=F^{I}\left(L_{I, t}, K_{I, t}, N_{I, t}, t\right) ; P_{t}^{I} I_{t}=P_{t}^{L} L_{I, t}+P_{t}^{K} K_{I, t}+P_{t}^{N} N_{I, t}$

(c) Consumption sector:

$C_{t}=F^{C}\left(L_{C, t}, K_{C, t}, N_{C, t}, t\right) ; P_{t}^{C} C_{t}=P_{t}^{L} L_{C, t}+P_{t}^{K} K_{C, t}+P_{t}^{N} N_{C, t}$

Equation (4) states that the output of intangibles is produced by labor and tangible capital in the intangible sector and that with factors paid their marginal products, the value of the intangibles produced equals the returns to labor and tangible capital used in that sector.

Since intangibles are supposed to be intermediates, the production functions for the tangible and consumption sectors ( 3 and 4 ) show that the volume of intangible output 
is simply an input into the production of tangible and consumption goods. Thus, intangibles are intermediate inputs and do not appear in total output:

$$
P_{t}^{Q^{\prime}} Q_{t}^{\prime}=P_{t}^{C} C_{t}+P_{t}^{I} I_{t}=P_{t}^{L} L_{t}+P_{t}^{K} K_{t}
$$

Where the prime ' indicates the case where intangibles are treated as intermediate expenditure and $\mathrm{L}=\mathrm{L}_{\mathrm{N}}+\mathrm{L}_{\mathrm{I}}+\mathrm{L}_{\mathrm{C}}$ and $\mathrm{K}=\mathrm{K}_{\mathrm{N}}+\mathrm{K}_{\mathrm{I}}+\mathrm{K}_{\mathrm{C}}$. Equation (7) shows the equality of GDP on the expenditure side and income side.

\subsection{Intangibles treated as capital}

Suppose that the intangible investment good is regarded as capital. The intangible capital stock, $R_{t}$ also accumulates according to the perpetual inventory model:

$$
R_{t}=N_{t}+\left(1-\delta_{R}\right) R_{t-1}
$$

where R depreciates at rate $\delta_{R}$. The production function and money flows for each sector can be written:

(a) Intangible sector:

$$
N_{t}=F^{N}\left(L_{N, t}, K_{N, t}, R_{N, t}, t\right) ; P_{t}^{N} N_{t}=P_{t}^{L} L_{N, t}+P_{t}^{K} K_{N, t}+P_{t}^{R} R_{N, t}
$$

(b) Tangible sector:

$$
I_{t}=F^{I}\left(L_{I, t}, K_{I, t}, R_{I, t}, t\right) ; P_{t}^{I} I_{t}=P_{t}^{L} L_{I, t}+P_{t}^{K} K_{I, t}+P_{t}^{R} R_{I, t}
$$

(c) Consumption sector:

$$
C_{t}=F^{C}\left(L_{C, t}, K_{C, t}, R_{C, t}, t\right) ; P_{t}^{C} C_{t}=P_{t}^{L} L_{C, t}+P_{t}^{K} K_{C, t}+P_{t}^{R} R_{C, t}
$$

In contrast to equation (4) the stock of intangible capital, $R_{t}$ rather than intangible output, appears as an input in the production functions and the payment to that stock; in addition, $P_{t}^{R} R_{t}$, appears in the payment equations rather than payment for the entire used up intermediate output. The corresponding output identity now includes the value of output of the intangible good on the production side, $P_{t}^{N} N_{t}$, and the payments to the stock of intangibles, $P_{t}^{R} R_{t}$, on the income side: 
$P_{t}^{Q} Q_{t}=P_{t}^{C} C_{t}+P_{t}^{I} I_{t}+P_{t}^{N} N_{t}=P_{t}^{L} L_{t}+P_{t}^{K} K_{t}+P_{t}^{R} R_{t}$

where the total output of the intangible good $\mathrm{N}=\mathrm{N}_{\mathrm{N}}+\mathrm{N}_{\mathrm{I}}+\mathrm{N}_{\mathrm{C}}$ and the intangible stock is $R=R_{N}+R_{I}+R_{C}$.

With intangibles being treated as capital output is increased from $P_{t}^{Q^{\prime}} Q_{t}^{\prime}$ to $P_{t}^{Q} Q_{t}$.

The investment rate increases from $P_{t}^{I} I_{t} / P_{t}^{Q^{\prime}} Q_{t}^{\prime}$ to $\left(P_{t}^{I} I_{t}+P_{t}^{N} N_{t}\right) / P_{t}^{Q} Q_{t}$ and the labor share falls from $P_{t}^{L} L_{t} / P_{t}^{Q^{\prime}} Q_{t}^{\prime}$ to $P_{t}^{L} L_{t} / P_{t}^{Q} Q_{t}$ where labor share is the proportion of total income paid to labor.

\subsection{Growth accounting}

Based on the growth accounting framework described in sections 4.1 and 4.2, the growth accounting relations can be written in the following way:

$$
\begin{aligned}
& \Delta \ln Q_{t}^{\prime}=s_{t}^{\prime L} \Delta \ln L_{t}-s_{t}^{\prime K} \Delta \ln K_{t}+\Delta \ln T F P_{t}^{\prime} \\
& \Delta \ln Q_{t}=s_{t}^{L} \Delta \ln L_{t}-s_{t}^{K} \Delta \ln K_{t}+s_{t}^{R} \Delta \ln R_{t}+\Delta \ln T F P_{t}
\end{aligned}
$$

where equation (13) shows the expression in the case where intangibles are expensed and equation (14) shows the case where they are capitalized. The equations show that the effect of including intangibles on growth is ambiguous, depending on the growth rate of real intangible investment. Moreover, the shares differ between (13) and (14) since both output and payment to capital differ.

In terms of decomposing labor productivity we get the following equations:

$$
\begin{aligned}
& \Delta \ln \left(Q^{\prime} / L\right)_{t}=s^{{ }^{L}} \Delta \ln \left(L^{Q A} / L\right)_{t}+s^{\prime K} \Delta \ln (K / L)_{t}+\Delta \ln T F P_{t}^{\prime} \\
& \Delta \ln (Q / L)_{t}=s^{L} \Delta \ln \left(L^{Q A} / L\right)_{t}+s^{K} \Delta \ln (K / L)_{t}+s^{R}(t) \Delta \ln (R / L)_{t}+\Delta \ln T F P_{t}
\end{aligned}
$$


Since the quality of labor hours varies we distinguish between employee hours, $L$, and quality adjusted employee hours, $L^{Q A}$. The factor shares are denoted with an $s$ and are averages of shares over which the time difference is taken, so that is a Törnquist index number. The share of capital is defined as one minus the share of labor. ${ }^{15}$ In equation (16) the level of output has risen, yet the growth rate may or may not rise depending on the growth rate of real intangible investment.

There are many different capital assets. For example, tangibles involve plants, buildings, vehicles and computer hardware; for intangibles there are $\mathrm{R} \& \mathrm{D}$, software, design, and so forth. Thus, the $\Delta \operatorname{lnK}$ and $\Delta \operatorname{lnR}$ terms must be constructed to incorporate these many types. According to Jorgenson and Griliches (1967), the theoretically correct capital measure in a production function is the services that capital provides into output. These services for each type of capital can be measured by the rental payments that a profit-maximizing firm would pay when it is renting its capital. Since firms rarely do this but rather buy the capital asset for a price $p^{A}$ and then use it over its lifetime, the market-clearing rental payment for an asset $\mathrm{B}, p^{B}$, can be derived as:

$$
p_{i t}^{B}=T_{i t}\left[r_{i t} p_{i, t-1}^{A}+\delta_{i t}^{A} p_{i t}^{A}-\left(p_{i t}^{A}-p_{i, t-1}^{A}\right)\right], \quad \quad \mathrm{B}=\mathrm{K}, \mathrm{R}
$$

where $T$ is a tax adjustment and $r$ is the rate of return on the asset. This equation holds for each type of capital $i$. The relation between this and the $\Delta \operatorname{lnK}$ and $\Delta \operatorname{lnR}$ terms in (14) can be derived as follows. The overall level of profit in the economy, $\varphi$, is by definition the overall payment to capital which is the sum of all rental payments to each capital type (Marrano et al. 2009). This can be written:

$$
\varphi_{t}=\sum_{i=1}^{n} p_{i t}^{K} K_{i t}+\sum_{i=n+1}^{m} p_{i t}^{R} R_{i t}
$$

Where there are $n$ tangible assets and $n+1$ to $m$ intangible assets. Second, the overall volume index of capital services can be shown to be a share weighted average of all the asset-specific $\Delta \operatorname{lnK}$ and $\Delta \operatorname{lnR}$ terms (Marrano et al. 2009):

\footnotetext{
${ }^{15}$ This is accurate if there are constant returns to scale at the overall economy level, but clearly an area where better measurement would be helpful.
} 
$\Delta \ln K_{t}=\sum_{i=1}^{n}\left(p_{i, t}^{K} K_{i t} / \varphi_{t}\right) \Delta \ln K_{i t}$

$\Delta \ln R_{t}=\sum_{i=n+1}^{M}\left(p_{i, t}^{R} R_{i t} / \varphi_{t}\right) \Delta \ln R_{i t}$

where the shares are the flow of rental payment for each asset as a share of total rental payments $(\varphi)$.

There are no time-varying depreciation rates available and they are therefore set constant over time. Moreover, there are no asset-specific rates of return, $r_{i}$, but in a competitive market $r_{i}$ will equalize across assets. Under these assumptions it is possible to solve for $r$ and $p^{K}$ in equation (17) and (18). Since the overall payment to capital is known in the economy it is possible to solve for the unobserved assetspecific rental prices that would ensure that all payments to capital assets added up to $\varphi$.

To summarize, growth accounting is implemented by collecting a time series of nominal investment in intangible and tangible assets. The series is deflated to get real investment series. Real capital stocks are constructed by using the perpetual inventory method, see equations (3) and (8). Market sector value added is re-calculated by including intangibles, see equation (7) and the operating surplus $\varphi$ for market sector value added is adjusted, see equation (18). A volume index of capital services of all capital inputs is calculated, ensuring that the asset rental payments are consistent with the adjusting operating surplus, see equations (17)-(20). A quality adjusted labor index to measure $L^{Q A}$ in equations (13)-(16) is constructed. Finally growth accounting in equations (13)-(16) can be carried out.

All data except for intangibles is based on EU KLEMS (2008). Data on investment in intangibles has been collected from different sources for the period 1993-2005 (see section 2). Business sector output deflators were used to create series of real intangible investment for all intangibles except software. The logic for choosing an output deflator instead of a wage deflator is explained by Corrado et al. (2009) and Marrano et al. (2009). Moreover, relatively little is know about depreciation rates of intangibles and therefore the best available estimates are the one presented in Corrado 
et al. (2009). ${ }^{16}$ Since there is no benchmark of initial capital stocks for intangibles it is assumed that the initial capital stock was zero in $1992 .^{17}$

\section{Growth accounting results}

Growth accounting for the Swedish business sector was performed for both GDP growth (see equations 13 and 14) and labor productivity growth (see equations 15 and 16). The growth of GDP and labor productivity is analyzed both including and excluding intangible capital. The analysis is based on the time period 1995-2004 and the sub-periods 1995-2000 and 2000-2004. The sub-periods were chosen for their value in analyzing the boom years of the Swedish ICT miracle and the years after the burst of the Swedish ICT bubble.

\subsection{Contribution to business sector growth}

Table 2 shows the result of growth accounting for the whole period of 1995-2004. When intangibles are excluded, the annual business sector growth was 3.9 percent. ICT tangible capital accounted for 0.4 percentage points of the value added increase while other tangible capital accounted for 1.3 percentage points. Labor and labor quality accounted for 0.1 and 0.3 percentage points, respectively. The residual, TFP, accounted for 1.8 percentage points. Thus, a considerable share of the Swedish business sector growth could not be explained by traditional types of inputs, namely labor and tangible capital.

Table 2 also presents figures of growth accounting, though this time with intangible assets included. The value added growth increases to 4.1 percent, indicating that intangibles had a positive effect not only on the level of value added, but also on the business sector growth. ICT tangible capital and non-ICT tangible capital accounted

\footnotetext{
${ }^{16}$ The depreciation rates are: 0.33 for computerized information, 0.2 for $\mathrm{R} \& \mathrm{D}$, mineral exploration, copyright and license cost, design, 0.4 for vocational training, purchased and own account organizational structure, 0.6 for adverting and market research.

${ }^{17}$ Setting initial capital stock to zero in 1992 might be subject to measurement errors since all of the true value of the benchmark will not have depreciated away in 1995 when measuring starts. In appendix A, the period 1997-2004 is used to see if the impact from intangibles is affected when the period from the year when the capital stock is assumed to be zero to the actual measurement period is prolonged.
} 
for 0.3 and 1.1 percentage points, respectively. The same holds for labor and labor quality with 0.1 and 0.3 percentage points of business sector growth rate. The largest difference came in the guise of intangible capital, which accounted for as much as 1.3 percentage of business sector growth. Hence, intangible capital accounted for 33 percent of total business sector growth in 1995-2004. TFP only accounted for 0.9 percentage points; hence, TFP decreased substantially when intangible capital was included in the growth accounting analysis.

For the sub-period 1995-2000, annual business sector growth was 4.5 percent when intangibles were excluded. Labor growth accounted for a considerably larger share of growth with 0.9 percentage points when compared to the period 1995-2004, implying that TFP accounted for 1.1 percentage points compared to 1.8 percentage points in 1995-2004. When intangible capital was included in the analysis, it accounted for nearly 1.7 percentage points of value added, resulting in TFP growth 0.4 percentage points as well. Thus, investment in intangible capital was considerable during the Swedish productivity boom of the 1990s.

For the period 2000-2004, annual business sector growth decreased to 3.2 percent with intangibles excluded. Both the contribution from ICT-tangible capital and nonICT tangible capital was lower than for the earlier period with 0.2 and 1.0 percentage points, respectively. Labor had a negative impact on growth with approximately -0.8 percentage points. TFP accounted for 2.6 percentage points of value added. When intangible capital was included, the growth rate decreased to 3.0 percent. Intangible capital accounted for 0.8 percentage points of business sector growth, while the impact of other inputs decreased slightly and TFP still accounted for 1.6 percentage points.

In total, the results show that intangible capital accounted for a large share of total business sector growth in 1995-2004. When intangible capital was included in the growth accounting analysis, TFP decreased considerably. The results for the subperiods 1995-2000 and 2000-2004 show that intangibles had a much larger impact on business sector growth in the earlier period, where inputs accounted for all growth and TFP was negative. For the period 2000-2004, TFP accounted for a larger share of business sector growth. 


\subsection{Contribution to labor productivity growth}

While GDP is a measure of the growth rate of all final goods and services produced, labor productivity measures the growth rate of GDP per amount of labor resources used to produce the output in the economy. Table 3 shows the labor productivity growth in the Swedish business sector 1995-2004 and for the sub-periods of 19952000 and 2000-2004.

For the period 1995-2004, the annual labor productivity growth was 3.7 percent when intangible capital was excluded. ICT tangible capital and non-ICT tangible capital accounted for 0.3 and 1.3 percentage points, respectively. Labor quality accounted for 0.3 percentage points while TFP accounted for 1.8 percentage points. When intangible capital was included, labor productivity growth increased slightly to 3.9 percent. The other inputs all accounted for slightly smaller shares, while intangible capital accounted for 1.3 percentage points of the growth rate and thus 34 percent of the total labor productivity growth. TFP accounted only for 0.9 percentage points of the productivity growth when intangibles were included.

For the sub-period 1995-2000, the labor productivity growth was 3.2 percent when intangibles were excluded, while it increased to 3.7 when they were included in the growth accounting analysis. Intangible capital accounted for 1.5 percentage points and thus more than 40 percent of the labor productivity growth. In total inputs accounted for most of the labor productivity growth implying in turn that TFP was only 0.4 percentage points.

For the period 2000-2004, the labor productivity growth was 4.4 percent and thus more than 1 percentage points higher than in 1995-2000. TFP was as high as 2.6 percentage points. When intangible capital was included the labor productivity, growth rate became 4.2 percent. Intangible capital then accounted for 1.0 percentage points and TFP decreased to 1.6 percentage points.

Table 4 shows the decomposition of intangible capital into the different categories of intangible capital. For the period 1995-2004, computerized information, innovative 
property and economic competencies accounted for $0.2,0.7$ and 0.4 percentage points of labor productivity growth. $R \& D$ accounted for the largest share with approximately 0.5 percentage points, indicating that investment in $R \& D$ was of very high importance to labor productivity growth. Design, vocational training and purchased organizational structure were also important for labor productivity growth, with a contribution of $0.2,0.1$ and 0.1 percentage points, respectively. Computerized information and advertisement also accounted for significant shares of labor productivity growth.

In total, intangibles accounted for as much as 34 percent of labor productivity growth in the business sector in 1995-2004. For the subperiod 1995-2000 the share was even higher than 40 percent. For the period 2000-2004 the impact of intangible capital decreased while TFP became considerably larger. Thus, the results for labor productivity growth follow the same pattern as for GDP growth in the business sector.

\subsection{Comparisons with other countries}

There have been a number of studies of the impact of intangibles on growth and productivity growth in other countries (see Corrado et al. 2009; Jalava, AulinAhmavaara and Alanen 2007; Marrano et al. 2009; Fukao et al. 2009; Hao et al. 2009). The results show that investment in intangibles accounted for a substantial part of GDP and labor productivity growth in Finland, France, Germany, Italy, Spain, the UK and US.

Figure 5 shows the TFP growth for the business sector in Finland, France, Italy, Japan, Sweden, the UK and US. The figure shows that TFP growth decreased for all countries when intangibles were included in the growth accounting model. For Japan and the UK the decrease was not very large. However, the figure clearly shows that for Sweden the TFP decrease was larger than in the other countries when intangible assets were included in the growth accounting analysis. Thus, investment in intangibles seems to be able to explain a larger part of the labor productivity growth in the Swedish business sector than in other countries both in absolute and relative terms. 


\subsection{ICT and intangible investment}

Sweden's high productivity growth can be largely traced to Swedish firms' large investment in ICT. Several studies have found that ICT had an important impact on productivity growth in Sweden as well as the United States (see Oliner and Sichel 2000; Gordon 2000; Stiroh 2002; Edquist and Henrekson 2006; Edquist 2008; Jorgenson et al. 2008). Edquist (2008) argues that ICT accounted for nearly 50 percent of labor productivity growth in the Swedish business sector 1995-2000. However, the results presented in table 3 show that investment in ICT capital only accounted for 16 percent when intangible assets are excluded.

There are two reasons why the results in this paper differ from Edquist (2008). The first is that software - which is usually defined as ICT-capital—is defined as an intangible investment in this paper. Table 4 shows that software accounted for 0.2 percentage points of labor productivity growth in 1995-2000. The second reason is that Edquist (2008) attributes a large share of the TFP growth to ICT, as TFP growth has been very high in the ICT-producing industry. This primarily stems from rapid technological change in the ICT-producing industry, but also to the fact that ICTproducing firms have made substantial investments in intangible assets that show up as TFP growth in the ICT-producing industry instead of as intangible investment. For example, the Swedish telecommunications firm Ericsson invested approximately 31 billon SEK in R\&D worldwide in 2008.

\section{Conclusions}

Few industrialized countries have attained such high growth rates of productivity as Sweden has since the mid-1990s. Economists have pointed out large Swedish investments in ICT and the market reforms of the 1980s to be the causes of the productivity boom. Yet this paper argues that extensive investment in intangible assets also had an important impact on productivity growth in 1995-2004.

To investigate the impact of investment in intangible assets, data on intangibles has been collected based on the framework developed by Corrado et al. (2005; 2006; 2009). Although the methodological framework must undergo improvements the 
results show that intangibles are quantitatively important. In 2004, total private spending on intangibles reached 300 billion SEK which is equivalent to 11 percent of GDP or 17 percent of value added in the business sector.

Based on the method in Corrado et al. (2005), 246 of the 300 billion of spending on intangibles could be considered as investment. The corresponding figure for physical capital in the business sector was 361 billion, which implies that investment in intangibles accounted for approximately two-thirds of the investment in physical capital. Thus, investment in intangibles accounted for 9 percent of total GDP in 2004.

The estimates of investment in different intangibles were used in a growth accounting framework to decompose economic growth and labor productivity growth in the Swedish business sector. When intangibles were excluded from the analysis, tangible assets, including ICT, accounted for 43 and 44 percent of economic and labor productivity growth, respectively. However, TFP still accounted for 45 percent of economic growth and 48 percent of labor productivity growth. Thus a large part of the productivity boom in 1995-2004 could not be explained by the inputs of tangible capital and labor.

When intangible assets were included in the growth accounting analysis the impact from tangible assets decreased to 35 percent of both economic and labor productivity growth in 1995-2004. Intangible capital accounted for as much as 33 percent of economic growth and 34 percent of labor productivity growth. As a result the TFP component decreased radically of both economic and labor productivity growth. As shown in figure 5 no other country that has been investigated so far exhibits such a large effect on TFP when intangibles are included in the growth accounting framework as Sweden. Consequently, increased investment in intangible assets explains a large share of the unexplained labor productivity growth.

When the two sub-periods are analyzed, it becomes evident that intangible capital had a particular impact on labor productivity growth in 1995-2000 - it accounted for 41 percent of labor productivity growth, while TFP growth only accounted for 11 percent of labor productivity growth. In the second sub-period intangible capital only 
accounted for 24 percent of labor productivity growth, while TFP accounted for 39 percent of labor productivity growth.

It is important to be aware of the potential problems of the growth accounting framework when the results are interpreted. Most significantly, it assumes that investment has an immediate and constant effect on growth. It is however most likely that investment in both tangible and intangible capital has an effect on growth over many years, rather than on an immediate and 1 to 1 basis. This means that the large investment in intangibles in the mid-1990s could have had large effects on productivity growth after the year 2000 as well, at which point, investment in intangible decreased. This could in turn explain the increased TFP growth in 20002004.

Economists have explained the strong productivity performance in the Swedish economy since the mid-1990s by citing the recovery effect, market reforms undertaken in the 1980s and the impact from the technological revolution of ICT, including innovations such as the Internet and mobile phones. Yet this paper has revealed another very important explanation; the large investment in intangible assets made by Swedish firms. These investments accounted for 300 billion SEK in 2004 or as much as 9 percent of GDP. Based on the growth accounting framework, investment in intangible assets accounted for as much as 34 percent of labor productivity growth in 1995-2004.

The estimation of investment in intangibles is no exact science, however; the methodological framework must undergo improvements. Nevertheless, the results presented here are robust and imply that the Swedish economy has become more dependent on intangible investment, including many knowledge intensive services. Since intangibles are important for understanding and analyzing economic and productivity growth, they should also be included in the National Accounts. 


\section{Tables and figures}

\subsection{Tables}

Table 1 Spending on intangible assets in Sweden 2004

\begin{tabular}{|c|c|c|c|c|}
\hline Type of intangible investment & Sources & $\begin{array}{l}\text { Total } \\
\text { spending } \\
2004(b n \\
\text { SEK) }\end{array}$ & $\begin{array}{l}\text { Percent of } \\
\text { intangibles }\end{array}$ & $\begin{array}{l}\text { Proportion of } \\
\text { spending } \\
\text { considered as } \\
\text { investment }\end{array}$ \\
\hline 1. Computerized information & & 48.2 & 16 & \\
\hline a) Computer software & EU-KLEMS & 48.2 & 16 & 1 \\
\hline b) Computerized databases & $\begin{array}{l}\text { Included in computer } \\
\text { software }\end{array}$ & n.a. & n.a & 1 \\
\hline 2. Innovative property & & 140.0 & 47 & \\
\hline a) $R \& D$ & OECD ANBERD & $68.3^{*}$ & 23 & 1 \\
\hline b) Mineral exploration & $\begin{array}{l}\text { SGU (Geological } \\
\text { Survey of Sweden) }\end{array}$ & 0.25 & 0.1 & 1 \\
\hline c) Copyright and license costs & Screen Digest & 1.5 & 0.5 & 1 \\
\hline $\begin{array}{l}\text { d) Development costs in } \\
\text { financial industry }\end{array}$ & EU-KLEMS & 6.6 & 2 & 1 \\
\hline e) Design & Statistics Sweden & 63.3 & 21 & 0.5 \\
\hline $\begin{array}{l}\text { 3. Economic competencies } \\
\text { a) Brand equity }\end{array}$ & & 109.3 & 37 & \\
\hline Adverting & $\begin{array}{l}\text { Swedish Institute for } \\
\text { Advertisement (IRM) }\end{array}$ & 37.4 & 12 & 0.6 \\
\hline Market Research & Statistics Sweden & 4.7 & 2 & 0.6 \\
\hline $\begin{array}{l}\text { b) Vocational training } \\
\text { c) Organizational structure }\end{array}$ & Statistics Sweden & 27.6 & 9 & \\
\hline Purchased & $\begin{array}{l}\text { Statistics Sweden and } \\
\text { Affärsvärlden }\end{array}$ & 27.3 & 9 & 0.8 \\
\hline $\begin{array}{l}\text { Own-account } \\
\text { Total Spending }\end{array}$ & Statistics Sweden & $\begin{array}{c}15.1 \\
\mathbf{3 0 0 . 4}\end{array}$ & $\begin{array}{c}5 \\
100\end{array}$ & 1 \\
\hline
\end{tabular}

Note: *To avoid double counting, the investment in R\&D is deducted with the R\&D investment for computer and related activities. The latter is based on the year 2003 while total R\&D investment is based on the year 2004 .

Sources: "Sources" in table 1 and own calculations. 
Table 2 Growth accounting with and without intangible assets for the business sector

\begin{tabular}{lccc}
\hline & $\mathbf{1 9 9 5}-\mathbf{2 0 0 4}$ & $\mathbf{1 9 9 5}-\mathbf{2 0 0 0}$ & $\mathbf{2 0 0 0 - 2 0 0 4}$ \\
\hline & Excluding & Intangible & Capital (\%) \\
\hline Annual value added growth & $\mathbf{3 . 9}$ & $\mathbf{4 . 5}$ & $\mathbf{3 . 2}$ \\
$\begin{array}{l}\text { Contribution of inputs } \\
\text { ICT tangible capital }\end{array}$ & & & \\
Non-ICT tangible capital & 0.4 & 0.5 & 0.2 \\
Labor & 1.3 & 1.6 & 1.0 \\
Labor quality & 0.1 & 0.9 & -0.8 \\
TFP & 0.3 & 0.4 & 0.3 \\
\hline & 1.8 & 1.1 & 2.6 \\
\hline Annual value added growth & $\mathbf{4 . 1}$ & $\mathbf{5 . 0}$ & \\
Contribution of inputs & & & $\mathbf{3 . 0}$ \\
ICT tangible capital & 0.3 & 0.5 & 0.2 \\
Non-ICT tangible capital & 1.1 & 1.4 & 0.8 \\
Labor & 0.1 & 0.8 & -0.7 \\
Labor quality & 0.3 & 0.3 & 0.3 \\
Intangible capital & 1.3 & 1,7 & 0.8 \\
TFP & 0.9 & 0.4 & 1.6 \\
\hline
\end{tabular}

Sources: EU KLEMS (2008), sources listed in table 1 and own calculations.

Table 3 Labor productivity growth accounting in the business sector

\begin{tabular}{lccc}
\hline & $\mathbf{1 9 9 5}-\mathbf{2 0 0 4}$ & $\mathbf{1 9 9 5}-\mathbf{2 0 0 0}$ & $\mathbf{2 0 0 0 - 2 0 0 4}$ \\
\hline & Excluding Intangible & Capital (\%) & \\
\hline $\begin{array}{l}\text { Labor productivity } \\
\text { growth }\end{array}$ & $\mathbf{3 . 7}$ & $\mathbf{3 . 2}$ & $\mathbf{4 . 4}$ \\
Contribution of inputs & & & \\
ICT tangible capital & 0.3 & 0.5 & 0.2 \\
Non-ICT tangible capital & 1.3 & 1.2 & 1.3 \\
Labor quality & 0.3 & 0.4 & 0.3 \\
TFP & 1.8 & 1.1 & 2.6 \\
\hline & & $\mathbf{3 . 7}$ & \\
\hline Labor productivity & $\mathbf{3 . 9}$ & & \\
growth & & & \\
Contribution of inputs & & 0.4 & 0.2 \\
ICT tangible capital & 0.3 & 1.0 & 1.0 \\
Non-ICT tangible capital & 1.1 & 1.5 & 1.0 \\
Intangible capital & 1.3 & 0.3 & 0.3 \\
Labor quality & 0.3 & 0.4 & 1.6 \\
TFP & 0.9 & & \\
\hline
\end{tabular}

Sources: EU KLEMS (2008), sources listed in table 1 and own calculations. 
Table 4 Contribution of intangible capital deepening to the annual change in labor productivity in the business sector (percentage points)

\begin{tabular}{l|ccc}
\hline & $\mathbf{1 9 9 5 - 2 0 0 4}$ & $\mathbf{1 9 9 5 - 2 0 0 0}$ & $\mathbf{2 0 0 0 - 2 0 0 4}$ \\
\hline 1. Computerized information & $\mathbf{0 . 1 5}$ & $\mathbf{0 . 1 8}$ & $\mathbf{0 . 1 0}$ \\
2. Innovative property & & & \\
a) R\&D & $\mathbf{0 . 7 4}$ & $\mathbf{0 , 8 3}$ & $\mathbf{0 . 5 9}$ \\
b) Mineral exploration & 0.48 & 0.53 & 0.39 \\
c) Copyright and license costs & 0.001 & 0.002 & 0.001 \\
d) Development costs in financial industry & 0.01 & 0.01 & 0.01 \\
e) Design & 0.04 & 0.06 & 0.02 \\
& 0.20 & 0.23 & 0.16 \\
3. Economic competencies & & & \\
a) Brand equity & $\mathbf{0 . 4 3}$ & $\mathbf{0 . 5 0}$ & $\mathbf{0 . 3 4}$ \\
Advertising & 0.10 & 0.18 & 0.05 \\
$\quad$ Market Research & 0.09 & 0.13 & 0.05 \\
b) Vocational training & 0.01 & 0.02 & 0.001 \\
c) Organizational structure & 0.12 & 0.14 & 0.11 \\
Purchased & 0.20 & 0.22 & 0.18 \\
Own-account & 0.13 & 0.15 & 0.10 \\
Total intangible capital deepening & 0.08 & 0.07 & 0.08 \\
\hline
\end{tabular}

Sources: EU KLEMS (2008), sources listed in table land own calculations. 
Table 5 Estimates of lower bound spending on intangible assets in Sweden 2004

\begin{tabular}{l|cccc}
\hline Type of intangible investment & $\begin{array}{c}\text { Total spending } \\
\text { 2004 (bn SEK) }\end{array}$ & $\begin{array}{c}\text { Lower bound } \\
\text { estimates 2004 }\end{array}$ & Investment & $\begin{array}{c}\text { Lower bound } \\
\text { investment }\end{array}$ \\
\hline 1. Computerized information & $\mathbf{4 8 . 2}$ & $\mathbf{4 8 . 2}$ & $\mathbf{4 8 . 2}$ & $\mathbf{4 8 . 2}$ \\
a) Computer software & 48.2 & 48.2 & 48.2 & 48.2 \\
b) Computerized databases & n.a. & n.a. & n.a. & n.a. \\
& & & & \\
2. Innovative property & $\mathbf{1 4 0 . 0}$ & $\mathbf{1 1 6 . 7}$ & $\mathbf{1 0 8 . 2}$ & $\mathbf{9 6 . 7}$ \\
a) R\&D & $68.3 *$ & 68.3 & 68.3 & 68.3 \\
b) Mineral exploration & 0.25 & 0.25 & 0.25 & 0.25 \\
c) Copyright and license costs & 1.5 & 1.5 & 1.5 & 1.5 \\
d) Development costs in & 6.6 & 6.6 & 6.6 & 6.6 \\
financial industry & & & & \\
e) Design & 63.3 & 40.1 & 31.7 & 20.0 \\
3. Economic competencies & $\mathbf{1 0 9 . 3}$ & $\mathbf{8 3 . 9}$ & $\mathbf{8 6 . 7}$ & $\mathbf{6 8 . 6}$ \\
a) Brand equity & & & & \\
$\quad$ Advertisement & 37.4 & 22.1 & 22.5 & 13.3 \\
$\quad$ Market Research & 4.7 & 4.7 & 2.8 & 2.8 \\
b) Vocational training & 27.6 & 22.1 & 27.6 & 22.1 \\
c) Organizational structure & & & & \\
$\quad$ Purchased & 27.3 & 27.3 & 21.8 & 21.8 \\
$\quad$ Own-account & 15.1 & 7.6 & 12.1 & 7.6 \\
Total Spending & $\mathbf{3 0 0 . 4}$ & $\mathbf{2 4 8 . 7}$ & $\mathbf{2 4 6 . 4}$ & $\mathbf{2 1 3 . 5}$ \\
\hline
\end{tabular}

Note: *To avoid double counting the investment in R\&D is deducted with the R\&D investment for computer and related activities. The latter is based on the year 2003 while total R\&D investment is based on the year 2004 .

Sources: "Sources" in table 1 and own calculations.

Table 6 Sensitivity analysis of labor productivity growth accounting

\begin{tabular}{l|ccccc}
\hline & $\begin{array}{c}\text { Base } \\
\text { case }\end{array}$ & I & II & III & IV \\
\hline LP growth & 3.9 & 3.8 & 3.9 & 4.2 & 3.9 \\
Contribution of inputs & & & & & \\
Tangible capital & 1.4 & 1.5 & 1.3 & 1.4 & 1.3 \\
Intangible capital & 1.3 & 0.8 & 1.0 & 1.4 & 1.4 \\
Labor quality & 0.3 & 0.3 & 0.3 & 0.3 & 0.3 \\
TFP & 0.9 & 1.3 & 1.2 & 1.1 & 1.0 \\
\hline
\end{tabular}

Note: (I) All conversion factors are halved except for software. (II) Doubled depreciation rates of intangibles except for brand equity, which is set to 0.9. (III) Machinery and equipment deflators are used for all intangibles except software instead of value added deflators. (IV) The period 1997-2004 is analyzed instead of the period 1995-2004.

Source: "Sources" in table 1 and own calculations. 


\subsection{Figures}

Figure 1 Labor- and total factor productivity growth in the business sector in EU-15, Japan and the US 1995-2005 (percent)

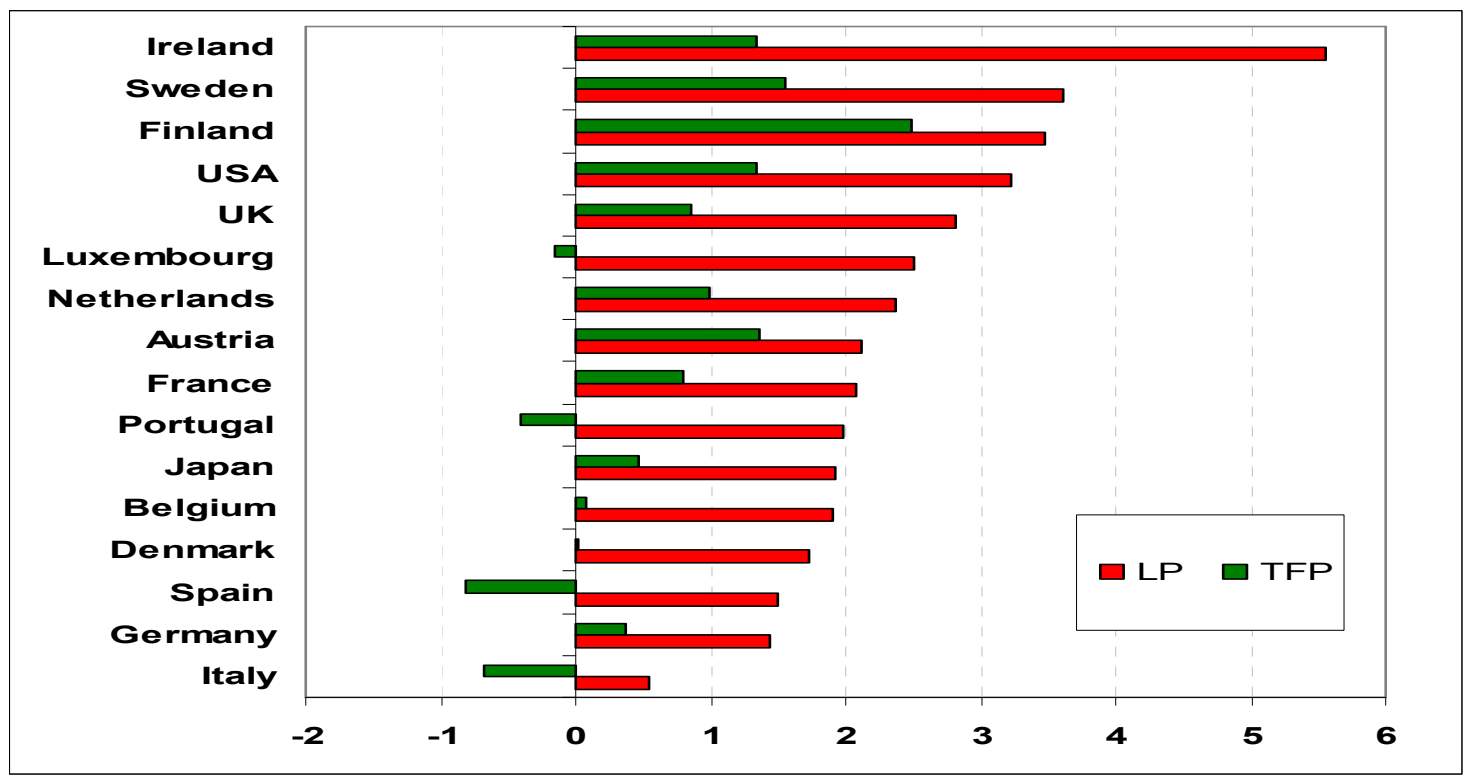

Note: Data for Greece is missing.

Sources: EU KLEMS (2008) and own calculations.

Figure 2 Business sector spending and investment in intangible capital and physical capital in Sweden

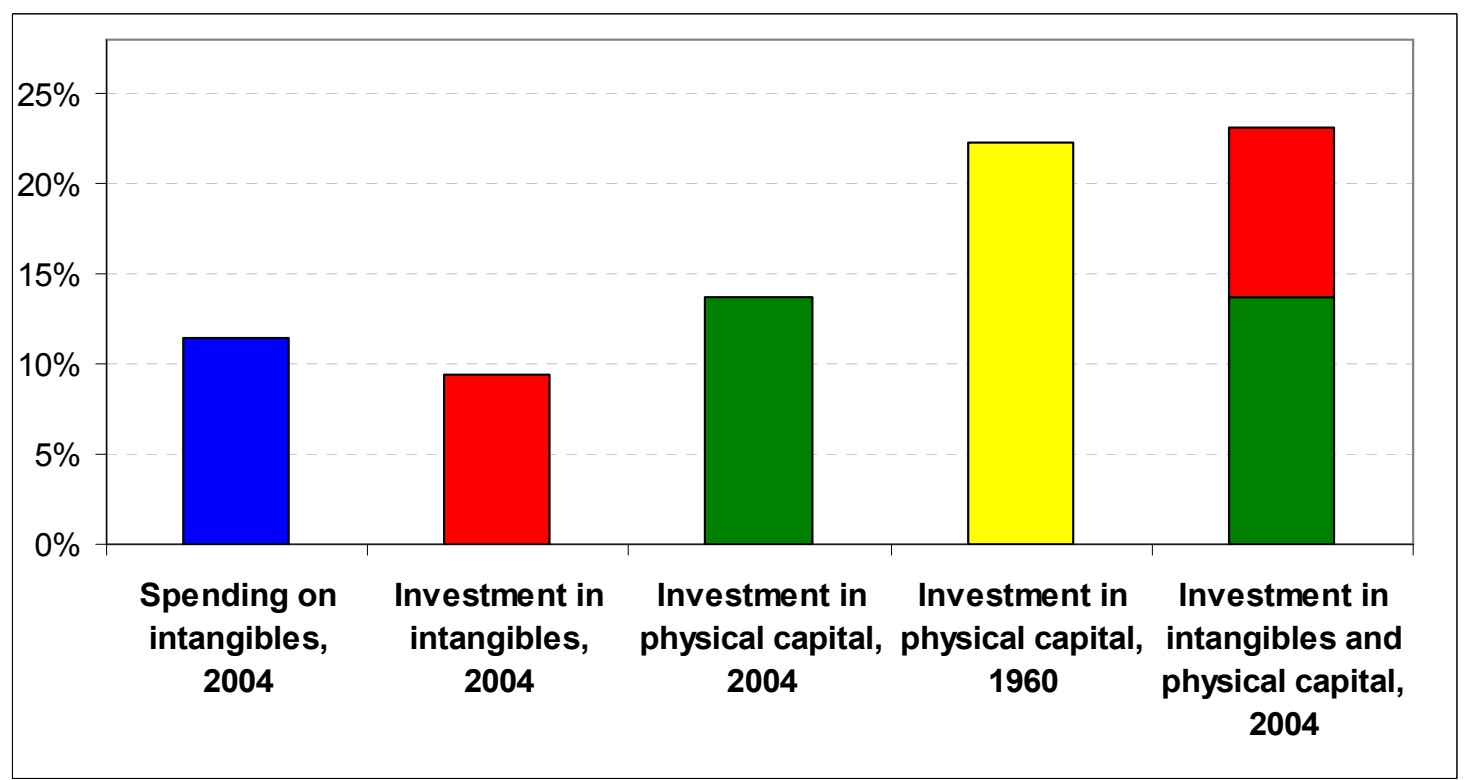

Sources: Own calculations based on the framework in Corrado et al. (2006) and Marrano and Haskel (2007) and Edvinsson (2005). 
Figure 3 Investment in intangibles as a share of total business sector value added and total GDP for Sweden, Japan, the UK and the US

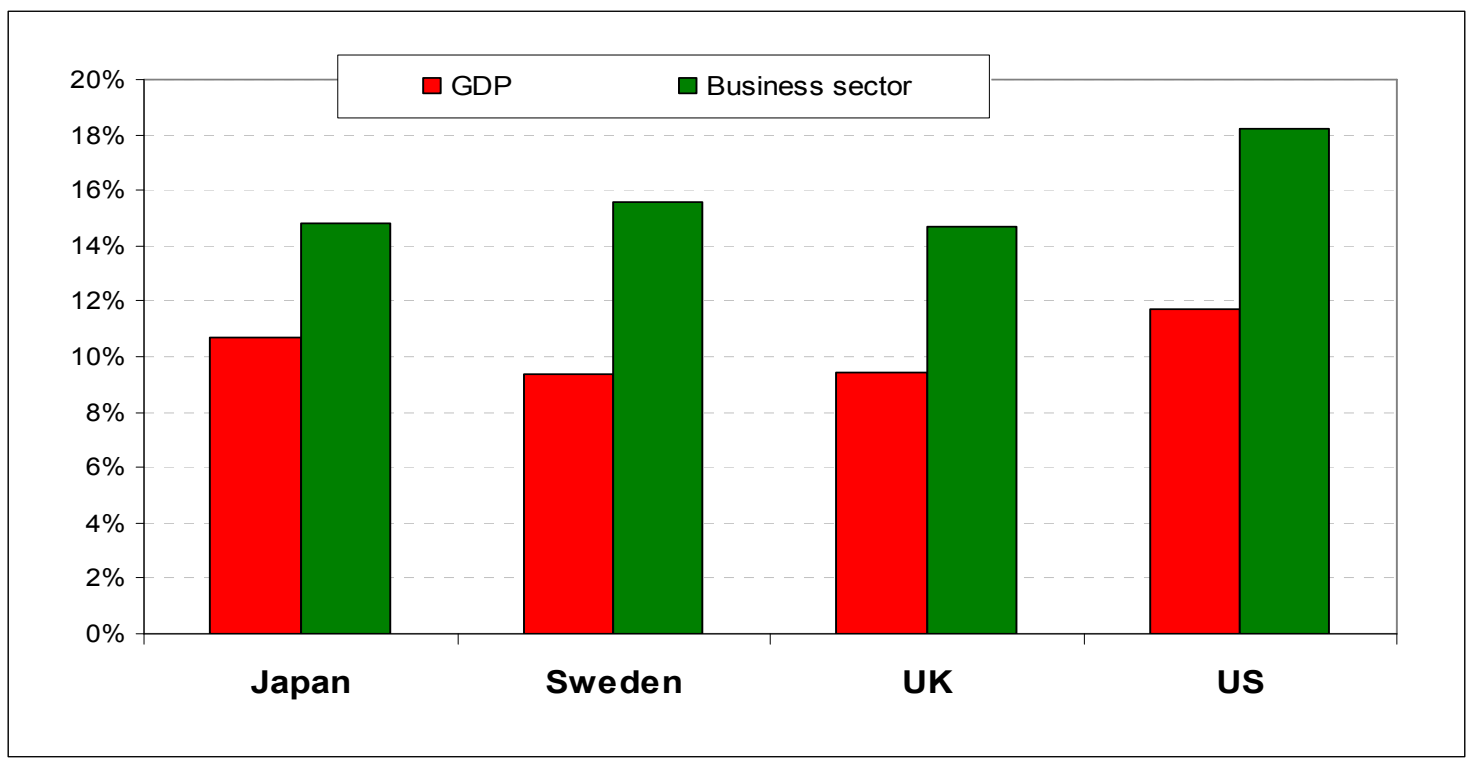

Note: Data for Sweden and the UK is for the year 2004, Japan for the years 2000-2005 and the US for the years 2000-2003.

Sources: Corrado et al. (2009), Fukao et al. (2009), Marrano and Haskel (2009) EU KLEMS (2008) and OECD (2009) and own calculations.

Figure 4 Relative investment in intangibles for different sub-categories in Japan, Sweden, the UK and the US

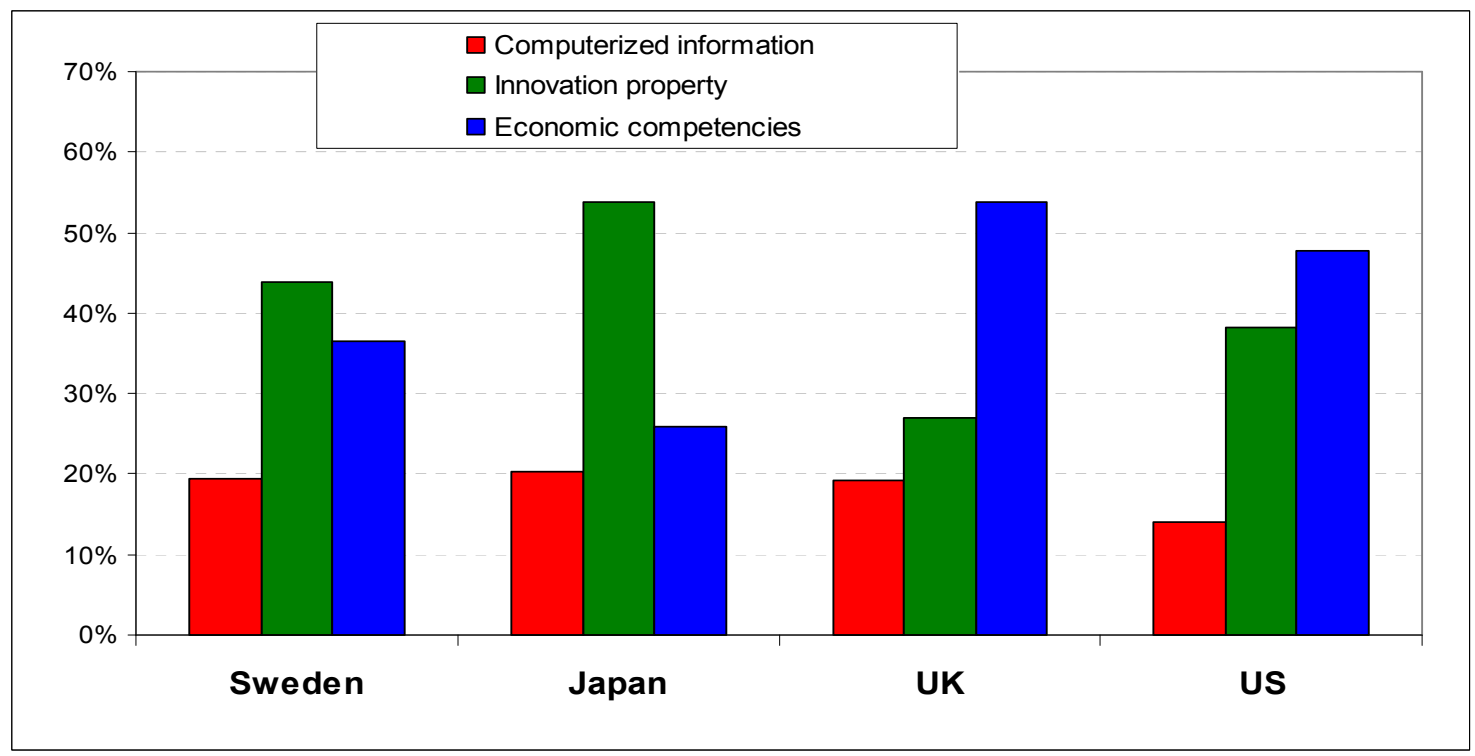

Note: Data for Sweden and the UK is for the year 2004, Japan for the years 2000-2005 and the US for the years 2000-2003.

Sources: Corrado et al. (2009), Fukao et al. (2009), Marrano and Haskel (2009) EU KLEMS (2008) and OECD (2009) and own calculations. 
Figure 5 TFP growth including and excluding intangibles in a number of different countries

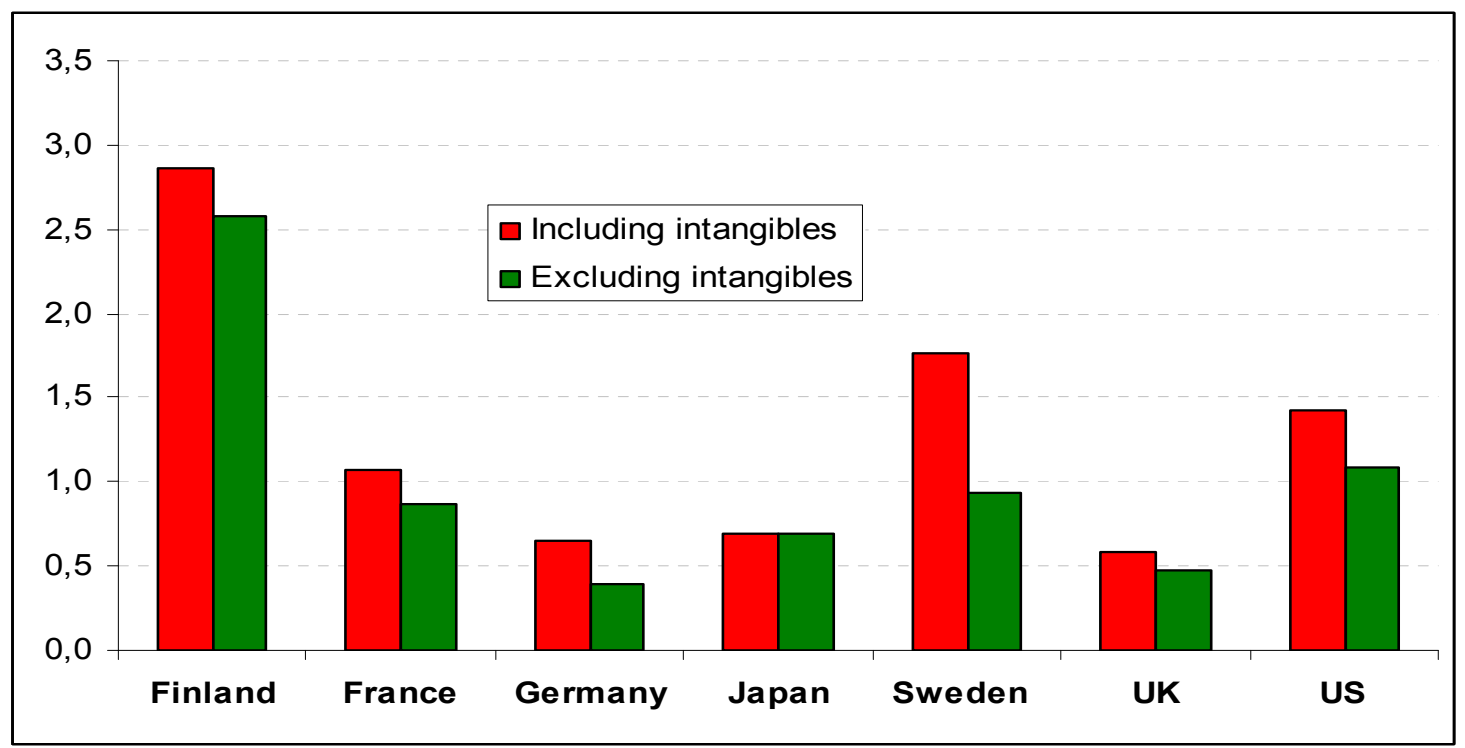

Note: Data is based on the following periods: Japan 1995-2005, Sweden 1995-2004 and the UK and US 1995-2003. The data for Japan is for the total economy, while UK and Swedish data is for the business sector and the US data for the non-farm business sector.

Sources: Corrado et al. (2009), Fukao et al. (2009), Hao et al. (2009), Marrano et al. (2009) and own calculations. 


\section{Appendix}

\section{Appendix A: Sensitivity Analysis}

This paper has presented estimates of spending and investment in intangible assets. Based on the description of the collected data in section 2, it is evident that there might be some uncertainty about the exactness of these estimates. It is therefore important to conduct some kind of sensitivity analysis, to try, to determine a reasonable lower bound for these estimates. Therefore, I changed the assumptions that the estimates are based on.

Based on the results presented in table 1, combined spending on mineral exploration, copyright and license cost and product development in financial services only accounted for 3 percent of the total spending on intangibles. Thus, it is likely that the impact from measurement errors for these categories would be small.

R\&D spending was 68 billion SEK or 23 percent of the share of total spending. R\&D figures for Sweden have been measured since 1965; the method for measurement is based on the Frascati Manual (2002), which has similar measurement guidelines for all OECD countries. It is therefore likely that measurement errors for R\&D are quite small-it is not unreasonable to assume that the estimates are accurate.

Spending on design accounted for 63 billion SEK and had thereby the second largest share of total spending with 21 percent. The design spending estimates are based on a number of assumptions. One is that all people with design as their occupation spend all of their time on design activities. It is however likely that some employees with design occupations are involved in R\&D related projects rather than design related projects. In addition, employees with design occupations outside the design sector are probably less likely to be involved in design projects. Thus, it is assumed that 100 percent of the employees with design occupations in the design sector all are involved in design related projects, but that only 50 percent of the employees outside the design sector are involved in design related projects. Design spending is thereby reduced to approximately 40 billion SEK instead of 63 billion SEK. 
Computer software had the third highest share with 16 percent of total spending or 48 billion SEK. Software spending is included in gross fixed capital formation and thus a part of GDP. This implies that the figures are estimated based on national accounts methods and therefore should not be subject to large measurement errors.

Brand equity, which includes both spending on advertisement and market research, accounted for 42 billion or 14 percent of total spending. Advertisement accounted for nearly 90 percent of the total spending on brand equity. The data is based on the Swedish Institute for Advertising which has collected this data on a yearly basis since 1975. It includes the actual spending on advertisement in media, but also spending on sponsorship events and gifts with the purpose of promoting products. However, it excludes the actual production cost of the advertisement.

If the definition of advertisement spending were narrower and only include the actual spending on advertisement in media and not sponsorship and other events the total spending on advertisement would be 22 billion SEK instead of 37 billion. This must be seen as the lowest possible estimate. The spending on market research was only 5 billion or 2 percent of total spending and it is therefore reasonable to believe that measurement errors would have a quite a low impact on total spending on intangibles.

Estimates for continuous vocational training (CVT) are based on a survey conducted in Sweden in 1999. Problematically, nearly no estimates exist for other years. It is therefore assumed that the same ratio of the total labor cost is spent on vocational training. One more CVT survey was conducted in 2005, but the answering ratio was so low that Statistics Sweden decided that the survey should not be published. Nonetheless, Statistics Sweden has reported some of the results of the survey to Eurostat. Unfortunately, the spending on CVT was not reported, but there is data on the total hours in CVT courses per 1000 hours worked and in 2005 this ratio was 10 , while it was 12 in 1999. This implies that the employees spent on average approximately 20 percent less of their time on vocational training in 2005 compared to 1999. If it is assumed that employees spent the same amount of time on vocational training in 2004 as in 2005 and that the spending per time unit of vocational training is the same over time, then the total spending on vocational training in 2004 would be 22 billion SEK instead of 28 billion SEK. 
Organizational structure (OS) accounted for 39 billion SEK or 13 percent of the total spending on intangibles. Purchased OS accounted for 27 billion, while own-account OS accounted for 12 billion. Purchased OS is measured as the turnover of business and management consultancy activities (SIC 7414). The turnover has been adjusted so that only products that include services that affect organizational structure are included. ${ }^{18}$ These services accounted for 88.3 percent of the total turnover of business and management consultancy activities (SIC 7414). It is plausible that these estimates are accurate.

Own-account OS is measured to be 20 percent of managers' compensation. As discussed in section 2.3.3.1 there are a number of problems with using managers' compensation as a measure of organizational structure. However, the estimates for Sweden are lower than in the UK and US. Thus, it is not likely that these estimates are overvalued compared to other countries. Yet, it is still unclear as to exactly how much of their time managers spend on organizational structuring. Thus, if it is assumed that managers only spend 10 percent of their time on organizational structure, spending on own-account organizational structure would be 6 billion SEK instead of 12 billion.

Table 5 shows the lower bound estimates for spending and investment in intangible assets in Sweden in 2004. According to table 5, the total spending based on lower bound estimates was 249 billion SEK instead of 300 billion SEK. Thus, the spending in terms of GDP was 9 percent instead of 11 percent. Based on the methods described in section 3 it is possible to estimate the share of spending that can be classified as investment. Table 5 also shows that the investment in intangibles was 214 billion SEK instead of 246 billion SEK. This implies that in terms of GDP, investment was 8 percent instead of 9 percent. The results for the lower bound estimates show that even if we change some of the assumptions that the estimates are based on, intangibles still accounted for a large share of GDP and thus had an important impact on the Swedish economy.

\footnotetext{
${ }^{18}$ The following services are assumed to affect organizational structure: advise regarding distribution, employees, mergers and acquisition, organizations, taxes, marketing, production, project leadership and administration. It has only been possible to estimate the share of these services for the year 2006 and the same shares are therefore used to estimate purchased organizational structure for other years.
} 
Not only the estimation of investment in intangible assets implies some uncertaintythe assumptions that the growth accounting model are based on do as well. Therefore, robustness is tested by changing some of these assumptions. Table 6 shows the results from this sensitivity analysis together with the base case (the chosen estimates as presented above). (I) shows the results when the conversion factors used to multiply expenditures into investment are halved for all categories of intangibles except software. (II) shows the results when all depreciation rates are doubled except for software and brand equity where the depreciation rate is set to 0.9 for the latter. (III) shows the results when machinery and equipment deflators are used for intangibles instead of value added deflators. (IV) shows the results when the period 1997-2004 is analyzed, which allows for much of the benchmark value that is zero in 1992 to depreciate away by the date that the growth accounting analysis is carried out.

Table 6 shows that intangible capital accounted for considerably less of the total labor productivity growth when the conversion factors are halved. Nevertheless, the contribution is still 0.8 percentage points or 20 percent of the total labor productivity growth. In all other cases (see table 6) the contribution from intangible capital was larger. Moreover, when growth accounting is carried out for the period 1997-2004 the impact from intangibles is 1.4 percentage points despite a longer period of depreciation from the year 1992 in which the benchmark value is set to zero.

The sensitivity analysis has shown that there are no exact estimates of the impact of intangibles. Nevertheless, the main findings of this paper-that investment in intangibles was an important cause of the Swedish productivity boom in 19952004 - seem robust. 


\section{References}

Affärsvärlden (2001-2004), Konsultguiden, Affärsvärlden, www.afv.se

van Ark, Bart, O’Mahony, Mary and Timmer, Marcel (2008), “The Productivity Gap between Europe and the United States: Trends and Causes," Journal of Economic Perspectives, Vol. 22, No. 1, pp. 2544.

Corrado, Carol, Hulten, Charles and Sichel, Daniel (2005), 'Measuring Capital and Technology: An Expanded Framework', In: Corrado, Carol, Haltiwanger, John and Sichel, Daniel (eds), Measuring Capital in the New Economy, National Bureau of Economic Research Studies in Income and Wealth, Vol. 65, pp. 11-45, The University of Chicago Press, Chicago and London.

Corrado, Carol, Hulten, Charles and Sichel, Daniel (2006), "The Contribution of Intangible Investments to US Economic Growth: A Sources-of-growth Analysis," NBER Working Paper. No. 11948.

Corrado, Carol, Hulten, Charles and Sichel, Daniel (2009), "Intangible Capital and U.S. Economic Growth," Review of Income and Wealth, Vol. 55, No. 3, pp. 661-685.

CVTS (1999), Continuing vocational training survey for Sweden, Statistics Sweden, www.scb.se

Edquist, Harald and Henrekson, Magnus (2006), “Technological Breakthroughs and Productivity Growth," Research in Economic History, Vol. 17, No. 3, pp. 275-301.

Edquist, Harald (2008), "Svensk produktivitetsutveckling och förutsättningar för en framgångsrik IKTpolitik,” Policy Paper, No. 23, The Research Institute of Industrial Economics, Stockholm.

Edvinsson, Rodney (2005), Growth, Accumulation, Crisis: With New Macroeconomic Data for Sweden 1800-2000, Almqvist \& Wiksell International, Stockholm.

Eliasson, Gunnar (2000), 'Making Intangibles Visible: The Value, the Efficiency and the Economic Consequences of Knowledge', In: Buigues, Pierre, Jacquemin, Alexis and Marchipont, Jean-Francois (eds), Competitiveness and the Value of Intangible Assets, Edward Elgar, Cheltenham.

EU KLEMS (2008), EU KLEMS Database, March 2008, www.euklems.net

Fukao, Kyoji, Miyagawa, Tsutomu, Mukai, Kentaro, Shinoda, Yukio and Tonogi, Konomi (2009), "Intangible Investment in Japan: Measurment and Contribution to Economic Growth," Review of Income and Wealth, Vol. 55, No. 3, pp. 717-736.

Frescati Manual (2002), Frescati Manual: Proposed Standard Practice for Surveys on Research and Experimental Development, OECD, Paris.

Galindo-Rueda, Fernando, Haskel, Jonathan and Pesole, Annarosa (2008), "How much does the UK employ, spend and invest in design?," CeRiBA Working paper, April.

Gordon, Robert J. (2000), "Does the 'New Economy' measure up to the Great Inventions of the Past?," Journal of Economic Perspectives, Vol. 14, No. 4, pp. 49-74.

Hao, Janet X., Manole, Vlad and van Ark, Bart (2009), "Intangible Capital and Growth - an International Comparison," The Conference Board, September.

Jalava, Jukka, Aulin-Ahmavaara, Pirkko, Alanen, Aku (2007), “Intangible Capital in the Finnish Business Sector, 1975-2005,” The Research Institute of the Finnish Economy, Helsinki.

Jorgenson, Dale W and Griliches, Zvi (1967), “The Explanation of Productivity Change," Review of Economic Studies, Vol. 34, pp. 249-83. 
Jorgenson, Dale W (2001), "Information Technology and the U.S. Economy," American Economic Review, Vol. 91, No. 1, pp. 1-32.

Jorgenson, Dale W, Ho, Mun S. and Stiroh, Kevin J. (2008), “A Retrospective Look at the U.S. Productivity Resurgence," Journal of Economic Perspective, Vol. 22, No. 1, pp. 3-24.

Landes, Elisabeth M. and Rosenfield, Andrew M. (1994), "The Durability of Advertising Revisited," Journal of Industrial Economics, Vol. 42, No. 3, pp. 263-276.

Marrano, Giorgio Mauro and Haskel, Jonathan (2006), "How Much Does the UK Invest in Intangible Assets?,” Working Paper, No. 578, Queen Mary University, London.

Marrano, Mauro G., Haskel, Jonathan and Wallis, Gavin (2009), "What Happened to the Knowledge Economy? ICT, Intangible Investment and Britain's Productivity Record Revisited", Review of Income and Wealth, Vol. 55, No. 3, pp. 686-716.

Nickell, Stephen J. (1996), “Competition and Corporate Performance," Journal of Political Economy, Vol. 104, No. 4, pp. 724-746.

OECD (2006), ANBERD Database 2005/06, Paris.

OECD (2009), Gross Domestic Product, Annual National Accounts, Paris.

Oliner, Stephen D. and Sichel, Daniel E. (2000), "The Resurgence of Growth in the Late 1990s: Is Information Technology the Story?,” Journal of Economic Perspectives, Vol. 14, No. 4, pp. 3-22.

Van Rooijen-Horsten, Myriam, van den Bergen, Dirk and Tanriseven, Murat (2008), "Intangible capital in the Netherlands: A benchmark," Discussion paper 08001, Statistics Netherlands Voorburg/Heerlen.

Schumpeter, Joseph A. (1939), Business Cycles: A Theoretical, Historical and Statistical Analysis of the Capitalist Process, McGraw-Hill, New York.

Screen Digest (2005), "World film production/distribution: production hits a plateau after six years of unbroken growth," Report.

Solow, Robert M. (1987), “We’d Better Watch Out,” New York Times, July 12, 1987, p. 36.

Stiroh, Kevin (2002), "Information Technology and the US Productivity Revival: What Do the Industry Data Say?," American Economic Review, Vol 92, No 5, pp. 1559-1576. 